Wenn ich in Folgendem eine ähnliche Methode angebe, so dürfte dieselbe sich durch eine besondere Einfachheit auszeichnen; freilich habe ich nur bei Agarplatten damit gauz befriedigende Resultate erzielt. Das Verfahren gestaltet sich folgendermaassen: Die zu conservirende Stelle der Agarplatte wird mit scharfem Messer quadratisch"umschnitten, dann mit dem Spatel herausgehoben und auf den Objectträger - und zwar in ein kleiues Tröpfchen Glycerin hilein, welches man vorher auf den Objectträger gebracht hat, iibertragen. Auf die Agarschiclit wird nun wieder ein Tröpfchen Glycerin gebracht und darauf das Deckglas gelegt. Die Grösse der Glycerintropfen muss so bemessen werden, dass der neben der Agarschicht noch übrig bleibende Raum zwischen Objectträger und Deckglas gerade ausgefüllt wird. Ein etwaiger Ueberschuss des Glycerins wird mit Hülfe eines Capillarrohrs, welches die Flüssigkeit begierig aufsaugt, entfernt. Dann wird in bekannter Weise ein Verschluss mit Lack hergestellt. - Die zu verwendenden Agarplatten (resp. -Schälchen) müssen in der feuchten Kammer gehalten werden, weil die Agarschicht sonst zu fest am Glase haftet.

Die Methode giebt, besonders bei recht dünner Agarschicht, ausgezeichnete Resultate. Die Präparate sind, wenn die Flächenausdehnung des Agars im Verhältniss zu der des Deckglases klein ist, d. h. wenn eine genügende Menge des conservirenden Glycerins vorhanden ist, dauernd unverändert haltbar. Dass die so conservirten Colonieen jederzeit bei schwacher ebenso wie bei den stälksten Vergrösserungen untersucht resp. photographirt werden können, ist selbstverständlich.

\title{
II. Kartoffelculturen in Reagenzglase.
}

Von Bolton ${ }^{5}$ ) und von Globig6) wurden im Jahre $1887 \mathrm{Me}$ thoden angegeben, Kartoffeln in Probirröhren mit Watteverschluss zu Culturzwecken vorzubereiten. $\operatorname{Roux}^{7}$ ) gab eine ähnliche Methode an, bei der er, um die Bespülung der Kartoffeln mit dem Condensationswasser zu vermeiden, die zu verwendenden Probirröhren einige Centimeter über ihrem Boden mit einer Einschnürung, Verengerung versah. Die verengte Stelle dient dem Kartoffelstïck zum Stätzpunkt. Roux verwendet wie Globig Kartoffelcylinder, die mit dem Korkbohrer ausgestochen und dann diagonal durchschnitten sind; er bringt diese Kartoffelkeile jedoch in rohem Zustande ein, während Globig bereits sterilisirte, gekochte Kartoffeln verwendet. Das Roux'sche Verfahren ist dann vou $\mathrm{Hu}$ eppe ${ }^{8}$ ) modificirt worden, welcher sich gewöhnlicher, unverengter Reagenzgläser bedient, auf deren Boden er zur Aufsaugung des Condensationswassers etwas sterilisirte Watte bringt, worauf dann das Kartoffelstück ruht.

Ein von mir geübtes Verfahren schliesst sich an die genannten Methoden eng an und ist folgendes: In ein gewöhnliches, sauberes und trockenes, unsterilisirtes Reagenzglas wird ein etwa $2 \mathrm{~cm}$ langes und etwa $7 \mathrm{~mm}$ im äusseren Durchmesser haltendes Stück Glasrohr, dessen scharfe Kanten in der Flamme verschmolzen sind, gebracht; dann wird der in der Globig'schen Weise zurechtgeschnittene, jedoch aus roher, nur mit der Bürste gereinigter Kartoffel hergestellte Kartoffellkeil eingefüllt, schliesslich ein Wattepfropf zurechtgemacht und eingedreht. So beschickte Röhrchen werden in grösserer Anzahl zunächst 45 Minuten im strömenden Dampf gekocht, an den beiden nächstfolgenden Tagen dann noch je $15-20$ Minuten in den strömenden Dampf gestellt. Die Kartoffeln nebst den Reagenzgläsern sind dann sicher steril und zu jederzeitigem Gebrauche fertig. Die kleinen Glasröhrchen tragen den Kartoffelkeil und verhindern dessen Berührung mit dem Condensationswasser.

\section{Conservirung von Agarplattenculturen auf dem Objectträger.}

Bei bacteriologischen Arbeiten hat sich von jeher das Bedürfniss geltend gemacht, das veränderliche Bild der auf den künstlichen Nährböden wachsenden Mikroorganismenverbände in bestimmten Stadien festzuhalten, zu conserviren. Leistet in diesem Sinne die Photographie schon die werthvollsten Dienste, so sind Methoden, die eine dauernde Conservirung des Objectes selbst in zweckmässiger Form gestatten, von bei weitem grösserer Bedeutung. Speciell hat man schon seit Jahren sich bemiiht, die Culturplatten entweder im Ganzen oder in einzelnen Theilen, diese dann in der Form mikroskopischer Präparate, festzuhalten. Methoden, welche den letzteren Zweck verfolgen, wurden von Garr ${ }^{1}$ ), Plaut²), Lipez ${ }^{3}$ ), $\mathrm{Jacobi}^{4}$ ) angegeben.

1) Garrè (Fortschr. d. Med. 1886, No. 12) umschneidet die zu conservirende Partie der Gelatineplatte, überträgt sie mit dem Spatel auf dell Objectträger, trocknet sie dann über Schwefelsäure auf $1 / 3$ bis ${ }^{1} / 2$ des $V_{0}$ lumens ein und kittet das Deckglas mit verfüssigter Glyceringelatine auf.

2) Plaut (Fortschr. d. Med. 1886, No. 13) überträgt die zu conservirende Stelle der Gelatineplatte nach der Umschneidung in einen auf den Objectträger gebrachten Wassertropfen, erwärmt den Objectträger bis zum Dickflüssigwerden der Gelatine, legt das Deckglas auf und umzieht das letztere nach dem Erstarren der Gelatine mit einem Lackring.

3) Lipez (Centr. f. Bact. Bd. 1, 1887 No. 13) überzieht das Deckglas mit inficirter Gelatine oder inficirtem Agar, lässt die Colonieen entstehen, 